\title{
SPECTROPHOTOMETRIC STUDY OF SOME SUBSTITUTED ISOXAZOLINES BY ISOBESTIC POINT METHOD
}

\author{
M. P. Patil \\ Deptt. Of Chemistry, Sevadal Mahila Mahavidyalaya,Nagpur
}

\begin{abstract}
Spectroscopic methods can be used to measure the dissociation constant provided that there is pronounced difference in the absorption between Molecular and ionic form of the substance. The ligands i.e. substituted isoxazolines $\left(\mathrm{L}_{1}, \mathrm{~L}_{2}, \mathrm{~L}_{3}, \mathrm{~L}_{4}, \mathrm{~L}_{5}, \mathrm{~L}_{6}\right)$ reacts with metal $\mathrm{Cu}(\mathrm{II})$ and forms a complex Vercille's method of isobestic points is used to study the complex formation.It was observed that the number of absorption curves are intersecting at a point showing 1:1 complex formation with $\mathrm{Cu}(\mathrm{II})$.
\end{abstract}

\section{Introduction}

The basic principal of spectroscopy deals with the study of measurement of interaction between radiation energy and matter particles Spectrophotometric study provides an important information regarding structure determination and confirmation of organic and inorganic molecules and complexes[1-4]. It also gives detail information about metal-ligand stability constant and confirmationof complex formation. Raghuwanshi[5] Khobragade[6], Pawar [7] Burghate[8], Bodkhe[9], Wagh[10], Ikhe[11], Purohit[12], Sawalakhe etal [13] carried out spectroscopic measurement by Job's method of continuous variation carried out spectroscopic measurement by Job's method of continuous variation.

\section{Experimental Method :-}

Complexes plays a very important role in numerous chemical and biological systems. Due to some properties of complexes like sharp melting points it was thought that investigate the complex formation of isoxazolines with the ligands 3-[2 hydroxy 5methyl phenyl] 5 phenyl $\Delta^{2}$ isoxazoline $\left(\mathrm{L}_{1}\right)$ and 3-[broro-2 hydroxy 5methyl phenyl]- 5 phenyl $\Delta^{2}$ isoxazoline $\left(\mathrm{L}_{2}\right)$, 3-[2hydroxy 5methyl-3nitro phenyl]- 5 phenyl $\Delta^{2}$ isoxazoline $\left(\mathrm{L}_{3}\right), 3-\left[5\right.$ chloro-2 hydroxy phenyl]- 5 phenyl $\Delta^{2}$ isoxazoline 
(L4) and3-[3Bromo-5 chloro-2 hydroxy -phenyl]- 5 phenyl $\Delta^{2}$ isoxazoline ( $\mathrm{L}_{5}$ ) 3-[5 chloro-2 hydroxy -3nitrophenyl]- 5 phenyl $\Delta^{2}$ isoxazoline ( $\mathrm{L}_{6}$ ) with $\mathrm{Cu}(\mathrm{II})$ were studied by spectrohotometric technique at $0.1 \mathrm{M}$ ionic strengthWhich is maintained by addition of appropriate amount of $1 \mathrm{~m}$ sodium perchorate solution.

During the spectroscopic analysis the absorption of a solution at fixed $\mathrm{pH}$ is recorded with respect to the wavelength region in visible region. The data obtained from spectrophotometric measurements is used for constructing the curves between absorption and wavelength in nm.

\section{Result and Discussion :-}

During spectroscopic measurements the colour of the solution was light yellow below pH 3.00,dark brown above 4,5 The change in colour with respect to $\mathrm{pH}$ of the solution indicated the commencement of complex formation.The solution employed are very dilute.The curves obtained from spectrophotometric measurements isobestic point at different wavelengths as under

\section{System}

1] $\mathrm{Cu}$ (II) with $\mathrm{L}_{1}$

2] $\mathrm{Cu}(\mathrm{II})$ with $\mathrm{L}_{2}$

3] $\mathrm{Cu}(\mathrm{II})$ with $\mathrm{L}_{3}$

4] $\mathrm{Cu}(\mathrm{II})$ with $\mathrm{L}_{4}$

5] $\mathrm{Cu}(\mathrm{II})$ with $\mathrm{L}_{5}$

6] $\mathrm{Cu}(\mathrm{II})$ with $L_{6}$
Isobestic point( wavelength in $\mathrm{nm}$ )

424

430

422

438

385

388

All the figure shows that $\mathrm{Cu}(\mathrm{II})$ forms $1: 1$ complex with all ligands $\mathrm{L}_{1}, \mathrm{~L}_{2}$, $\mathrm{L}_{3}, \mathrm{~L}_{4}, \mathrm{~L}_{5}$, and $L_{6}$. 

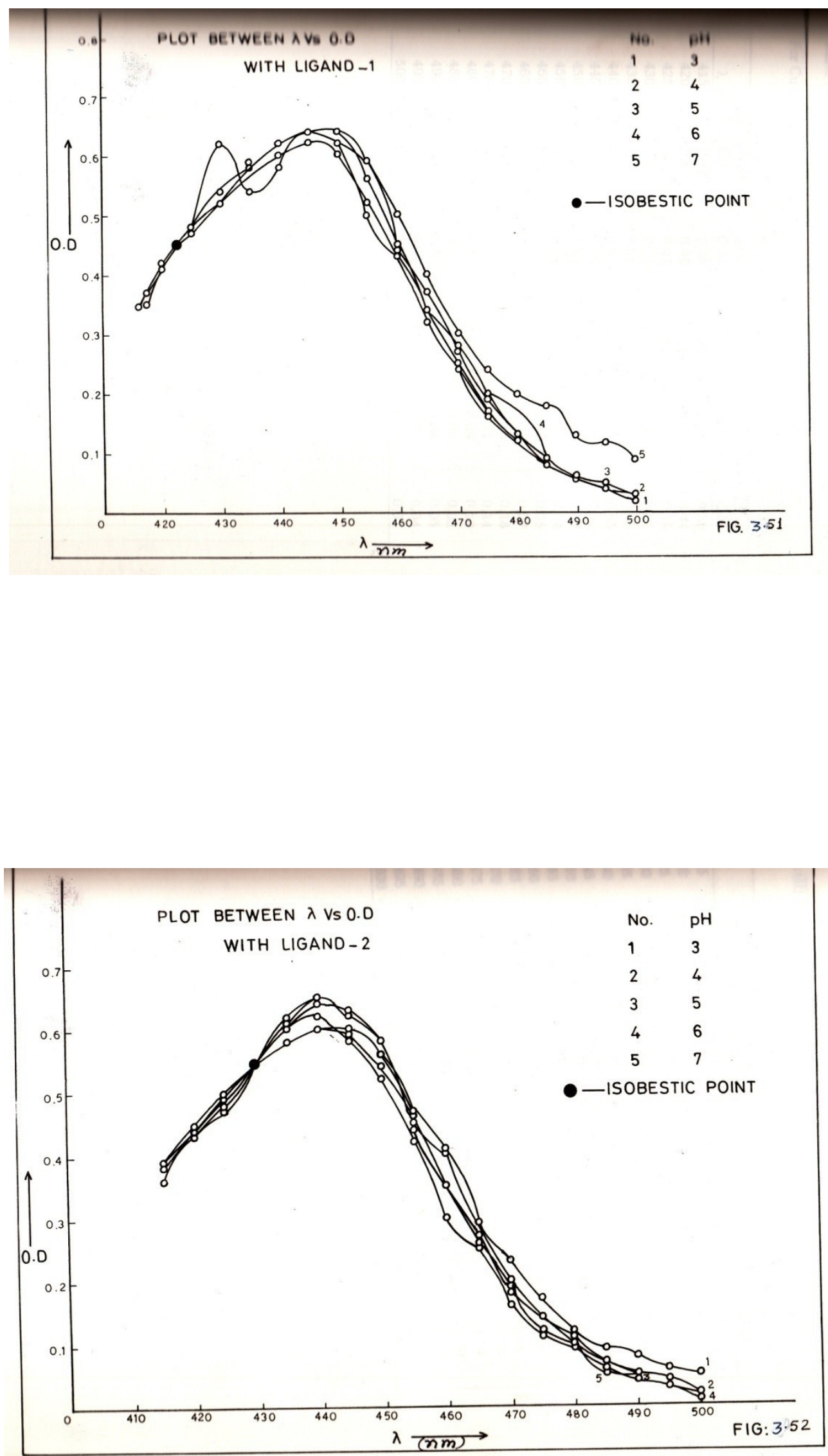

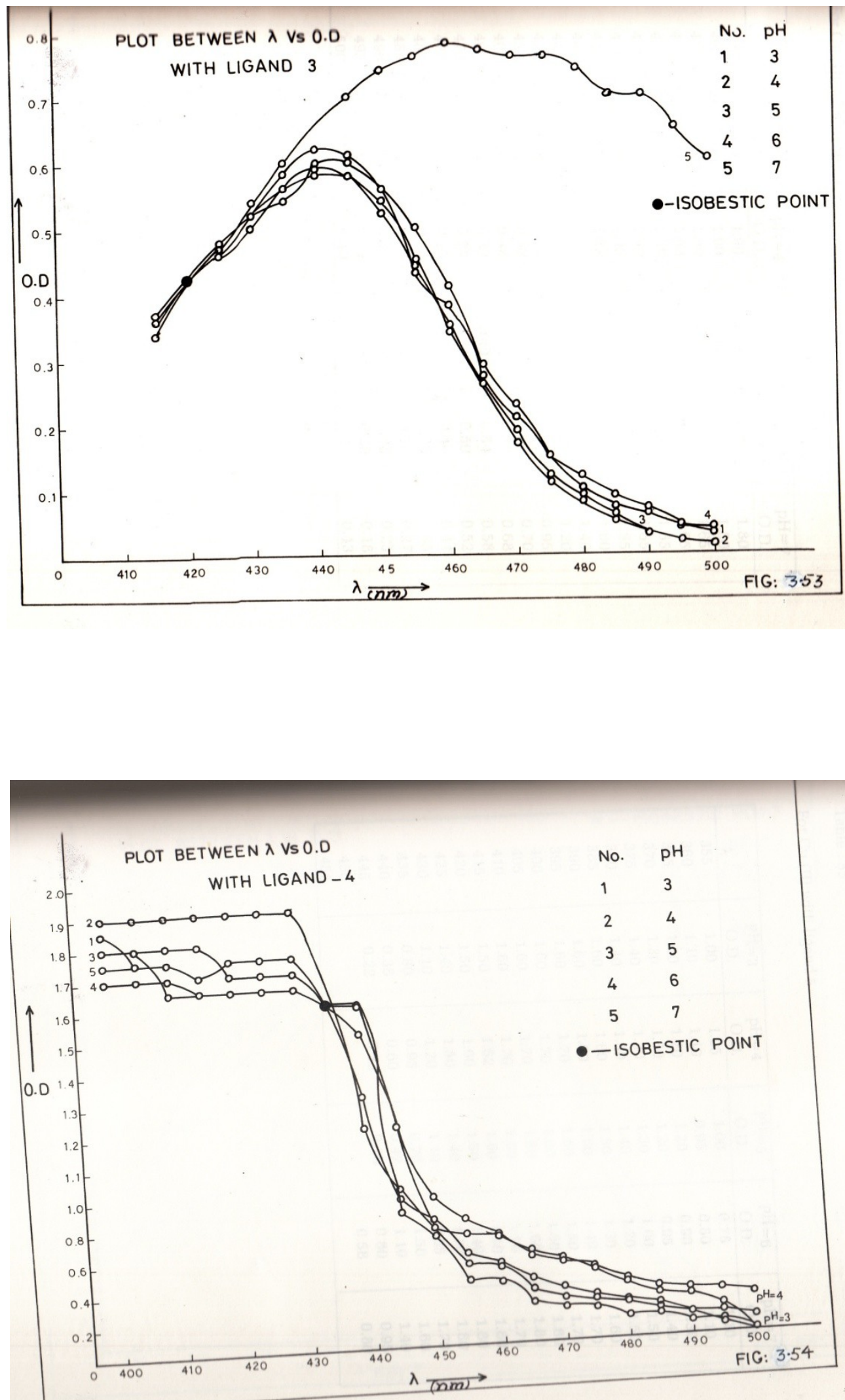

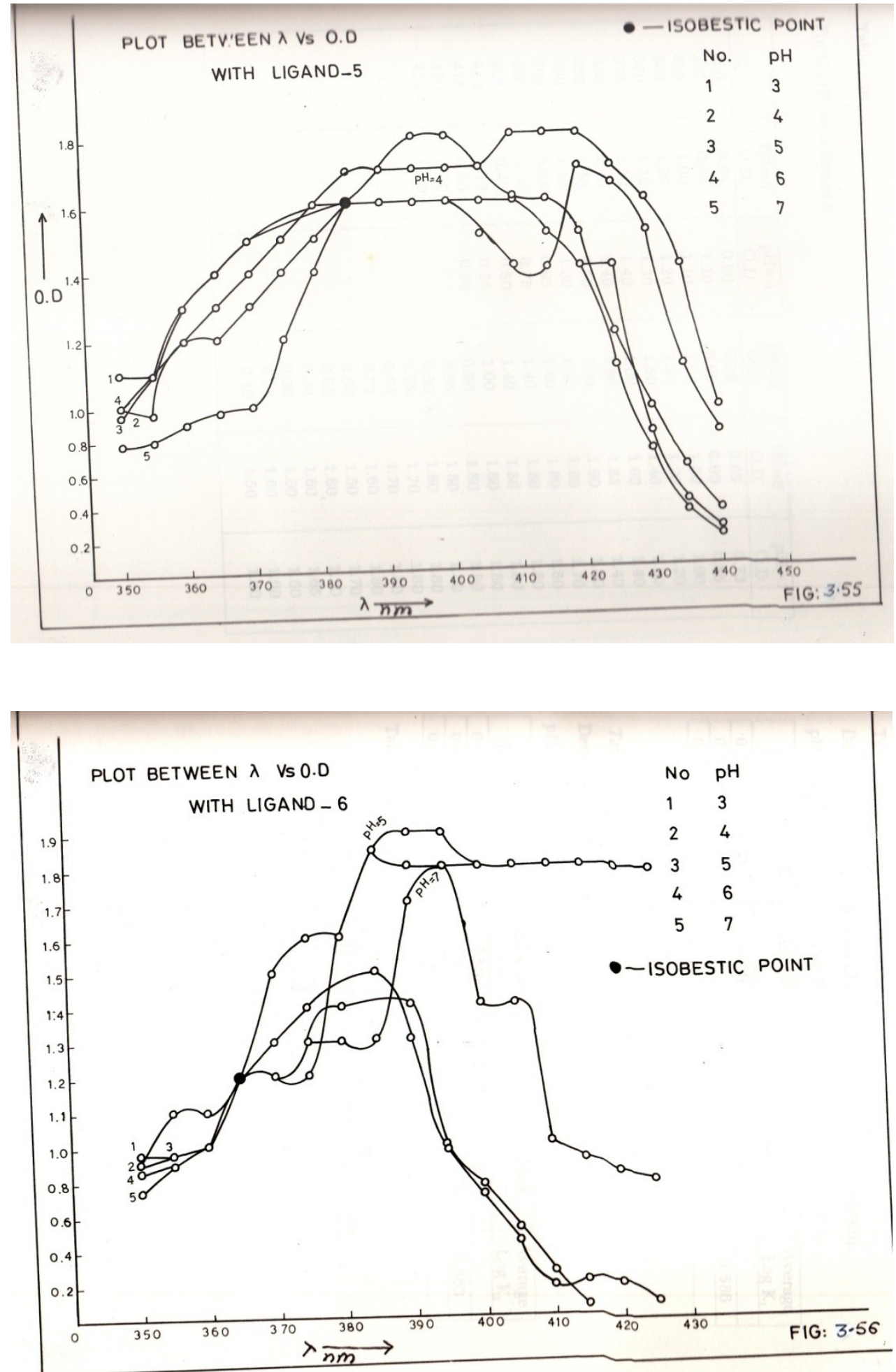


\section{REFERENCES :-}

Banerjee, and S.N., (1970). Inorg. Nucl. Chem.,32,686,3333.

Manimekalai A., and Thanikachalam , (1991). J. Chem.Soc., 68.

Sawalakhe, P.D., (1992). Ph.D. Thesis in Chemistry submitted to

Amravati University, Amravati.

Narwade M.L. and khobragade B.G., (1983). Acta Ciencia Indica,IX C, 32.

Raghuwanshi.P.B., Doshi. A.G. and Narwade M.L, (1996). Indian., J

Chem. Soc., 73,21-24.

Khobragade B.G, ., (1999). Ph.D.Thesis in Chemistry submitted to

Amravati University.

Pawar, R.P., Narwade M.L., and Chicholkar M.M. (2000). Oriental J.

Chem. 16 8. 8.Burghate,A.S., Ph.D.Thesis in Chemistry submitted to Amravati (1)147.

Bodkhe, P. S., Patil K. N., Narwade M. L., Doshi. A. G., Asian J. Chem. 168.

Wagh. S. P., (2004). Ph.D. Thesis in Chemistry submitted to Amravati University

Ikhe, S.A. and Narwade M.L, (2005). Indian., J Chem. 44A, 1203.

Purohit D.N. ,Rostami.S,Rezwi,B. Ghiasv and,A.R. ., (2006). Asian J. Chem, 18(1), 689-690.

Sawalakhe,P.D. and Narwade M.L.samyal J.,2, 3o(1998) 